\title{
Trends in roken in Amsterdam tussen 1994 en 2016
}

\author{
Henriëtte Dijkshoorn · Daan G. Uitenbroek
}

Geaccepteerd op: 3 mei 2021 / Published online: 2 juni 2021

(C) The Author(s) 2021

Samenvatting Vanaf 1990 voerde de overheid diverse maatregelen in om roken tegen te gaan. We gaan na of dit in Amsterdam samengaat met een daling van het percentage rokers, dagelijkse rokers en zware rokers onder 19- tot en met 74-jarige Amsterdammers op basis van gegevens uit de vierjaarlijkse GGD-Gezondheidsmonitor. Tussen 1994 en 2016 daalde het percentage rokers in Amsterdam van $43 \%$ naar $27 \%$ en landelijk van $38 \%$ naar $24 \%$. In heel Nederland daalde het cijfer de gehele periode; in Amsterdam stagneerde de afname in 2008, vooral onder 19- tot en met 34-jarigen. Onder Amsterdamse vrouwen daalde het percentage dagelijkse rokers sterker dan het percentage rokers. Dagelijks roken nam onder vrouwen ook na 2008 af, maar niet onder mannen. Wel daalde vanaf 1994 onder zowel mannen als vrouwen het percentage zware rokers ( $\geq 20$ sigaretten/dag). Kortom, de ingezette daling van roken vanaf de jaren negentig stagneerde in Amsterdam in 2008, vooral onder jongvolwassenen, terwijl deze daling elders in Nederland continueerde. Wel is in Amsterdam het aandeel zware rokers ook na 2008 afgenomen. Extra beleidsinspanningen zijn nodig om het streefpercentage van 5\% rokers in 2040 in Amsterdam te bereiken, vooral gericht op de jongvolwassenen.

Trefwoorden gezondheidsenquête $\cdot$ tabak . trendcijfers $\cdot$ preventie

H. Dijkshoorn (四)

Afdeling Epidemiologie, Gezondheidsbevordering en Zorginnovatie, GGD Amsterdam, Amsterdam, Nederland hdijkshoorn@ggd.amsterdam.nl

D. G. Uitenbroek

Quantitative Skills, Hilversum, Nederland

\section{Trends in smoking in Amsterdam, the Netherlands, from 1994 to 2016}

Abstract From 1990 onwards the Dutch government implemented policy measures to prevent smoking. We studied whether this has led to a lower number of smokers in Amsterdam. We used data about smoking, daily smoking and excessive smoking among 19to 74-year-old residents collected in the quadrennial health monitor by the municipal health services of Amsterdam. From 1994 to 2016 the number of smokers decreased from $43 \%$ to $27 \%$ in Amsterdam and nationwide from $38 \%$ to $24 \%$. In Amsterdam the smoking numbers stabilised after 2008, especially among 19- to 34-year-olds, whereas the national figures continued to decline. Among Amsterdam women, the decline in the percentage of daily smokers was larger than the decline in the percentage of smokers generally. Moreover, the decline of daily smoking among women was observed throughout the study period, but stagnated among men. Among both men and women, the number of excessive smokers ( $\geq 20$ cigarettes/day) dropped from 1994. In short, the decrease of smoking in Amsterdam stagnated in 2008, especially among young adults and men, while it continued nationwide. In Amsterdam the decline in excessive smoking continued throughout the study period. Additional policy measures are necessary to achieve the aimed percentage of 5\% smokers in 2040 in Amsterdam, with a focus on the high number of smoking young adults.

Keywords health survey - tobacco · trend figures · prevention 


\section{Inleiding}

Roken is schadelijk voor de gezondheid en verhoogt het risico op diverse gezondheidsproblemen, zoals vormen van kanker, COPD en hart- en vaatziekten. In 2016 overleden ruim 19.500 Nederlanders ten gevolge van een aan roken gerelateerde aandoening [1]. De overheid heeft sinds 1990 een aantal maatregelen genomen om roken tegen te gaan en nietrokers te beschermen. Veel van deze maatregelen staan in de Tabaks- en rookwarenwet. Het gaat daarbij bijvoorbeeld om het rookvrij maken van publieke ruimten, werkplekken, personenvervoer en horeca. Ook de verkoop van tabak is aan steeds strengere regels gebonden, prijzen van rookwaren zijn verhoogd, reclame en marketing voor tabaksproducten is verboden en sigarettenpakjes bevatten een waarschuwend plaatje. Verder is de leeftijdsgrens voor de verkoop van tabak op 1 januari 2014 van zestien naar achttien jaar gegaan [2]. Ook wordt ondersteuning bij het stoppen met roken vergoed vanuit de Zorgverzekeringswet [3].

In 2018 heeft het kabinet het Nationaal Preventieakkoord gesloten met een groot aantal organisaties, zoals koepelorganisaties van de zorg, onderwijsinstellingen, gemeenten en bedrijven. Hierin is afgesproken dat het percentage rokende volwassenen in 2040 moet zijn gedaald naar maximaal $5 \%$ en dat er een rookvrije generatie moet zijn gerealiseerd, dat wil zeggen dat jongeren niet meer starten met roken en dat zwangere vrouwen niet meer roken. Verschillende maatregelen moeten ervoor zorgen dat deze streefcijfers gehaald worden. Voorbeelden zijn een verhoging van de accijns op tabak, een verbod om te roken bij schoolpleinen, een rookvrije omgeving bij sportverenigingen en speeltuinen, een vermindering van het aantal verkooppunten van tabak en een uitbreiding van toegankelijke ondersteuning bij stoppen met roken [4].

Ook de gemeente Amsterdam besteedt sinds de jaren negentig van de vorige eeuw steeds meer aandacht aan de preventie van roken, bijvoorbeeld door het inzetten van interventies op scholen en vanuit de jeugdgezondheidszorg, en door deelname aan de Stoptober-campagne. Vanwege de impact die roken op de volksgezondheid heeft, heeft Amsterdam er in 2016 als eerste gemeente voor gekozen om tabaksontmoediging in een aparte beleidsnotitie op te nemen. De beleidsnotitie had twee speerpunten: voorkomen dat jongeren beginnen met roken en het stimuleren van Amsterdammers om te stoppen met roken. Daarvoor werden maatregelen ingezet als het programma Gezonde School, het aanbieden van begeleiding om roken te stoppen door verloskundigen en een verbod op inpandige rookruimten in gemeentelijke gebouwen [5].

In Nederland is landelijk het aandeel rokers tussen 1989 en 2011 afgenomen. Onder mannen daalde het cijfer van $44 \%$ naar $30 \%$ en onder vrouwen van $32 \%$ naar 23\% [6]. Van 2011 tot en met 2016 was sprake van een verdere afname tot $27 \%$ onder mannen en $19 \%$ onder vrouwen. Ook daarna daalde het cijfer - in 2019 rookte $25 \%$ van de mannen en $18 \%$ van de vrouwen [7]. In dit artikel gaan we na of de ingevoerde beleidsmaatregelen tegen roken ook in Amsterdam zijn samengegaan met een daling van het percentage rokers onder mannen en vrouwen en in verschillende leeftijdsgroepen. Ook willen we inzicht krijgen in de trend in dagelijks roken en zwaar roken (20 sigaretten of meer per dag) in Amsterdam. Om deze vragen te beantwoorden maken we gebruik van gegevens afkomstig uit de periodieke Gezondheidsmonitor van de GGD Amsterdam.

\section{Methode}

\section{Onderzoekspopulatie}

De data voor dit onderzoek zijn tussen 1994 en 2016 verzameld in het kader van de periodieke Gezondheidsmonitor onder een aselecte steekproef van zelfstandig wonende volwassen inwoners van Amsterdam, uitgevoerd door de GGD Amsterdam. Tabel 1 laat zien op welke manier de dataverzameling in de verschillende onderzoeksjaren plaatsvond.

\section{Onderzoeksgegevens}

In de Gezondheidsmonitor van de GGD Amsterdam werd het rookgedrag in kaart gebracht met de vraag 'Rookt u weleens?'. Aan rokers werd gevraagd naar het gemiddelde aantal sigaretten dat ze per dag roken. Daarmee konden zware rokers (minimaal 20 sigaretten per dag) worden onderscheiden van rokers die gemiddeld minimaal 1 sigaret per dag roken (verder genoemd: dagelijkse rokers). De vraagstellingen

Tabel 1 Methodiek Gezondheidsmonitor onder zelfstandig wonende volwassen inwoners van Amsterdam door GGD Amsterdam, 1994-2016

\begin{tabular}{|c|c|c|c|c|}
\hline Jaar & Methode & Leeftijdsgrens & Aantal respondenten & Respons \\
\hline 1994 & Mondelinge interviews aan huis & 16 jaar en ouder & $n=5.121$ & $61 \%$ \\
\hline 2000 & Mondelinge interviews aan huis & 16 jaar en ouder & $n=2.673$ & $51 \%$ \\
\hline 2004 & Mondelinge interviews op locatie & 18 jaar en ouder & $n=1.736$ & $44 \%$ \\
\hline 2008 & Schriftelijke en online vragenlijst; klein aantal mondelinge interviews ( $n=86)$ & 16 jaar en ouder & $n=6.511$ & $50 \%$ \\
\hline 2012 & Schriftelijke en online vragenlijst; klein aantal mondelinge interviews $(n=308)$ & 19 jaar en ouder & $n=7.615$ & $38 \%$ \\
\hline 2016 & $\begin{array}{l}\text { Schriftelijke en online vragenlijst; klein aantal mondelinge interviews }(n=94) \text { en telefonische } \\
\text { interviews }(n=28)\end{array}$ & 19 jaar en ouder & $n=8.869$ & $38 \%$ \\
\hline
\end{tabular}


zijn tussen 1994 en 2016 enigszins gewijzigd. Zo waren er tot en met 2008 twee ontkennende antwoordmogelijkheden op de vraag naar rookgedrag: 'nee, maar vroeger wel' en 'nee, ik heb nooit gerookt'. Op die manier werden rokers, nooit-rokers en ex-rokers direct onderscheiden. Vanaf 2012 werd dit in een extra vraag gedaan: 'Heeft u vroeger wel gerookt?' In 2016 werd een uitleg toegevoegd: 'We bedoelen hier het roken van alle soorten tabaksproducten, maar niet het gebruik van een elektronische sigaret.'

De landelijke gegevens over roken zijn afkomstig uit de Gezondheidsenquête van het CBS en betreffen de leeftijdsgroep van achttien jaar en ouder. In de landelijke Gezondheidsenquête heeft in 2001, 2010 en in 2014 een trendbreuk plaatsgevonden door veranderingen in de vraagstelling en de dataverzamelingsmethode [6-8].

\section{Statistische analyse}

De analyses van de gegevens uit de Gezondheidsmonitor zijn beperkt tot deelnemers van negentien jaar en ouder uit Amsterdam. Er zijn wegingsfactoren berekend om te corrigeren voor verschillen tussen de samenstelling van de onderzoekspopulatie en de bevolkingssamenstelling in het betreffende onderzoeksjaar voor onder meer geslacht, leeftijd, herkomst en geografie (wijk, stadsdeel, gebied). In de resultaten staan de gewogen prevalenties.

Om de trend in Amsterdam met de landelijke trend te kunnen vergelijken en te voorkomen dat verschillen veroorzaakt worden door een verandering van de leeftijdsopbouw van de Amsterdamse bevolking, zijn de gegevens voor roken in Amsterdam apart voor mannen en vrouwen gestandaardiseerd naar de leeftijdsopbouw in Nederland op 1 januari 2000. Rondom de prevalentiecijfers zijn 95\%-betrouwbaarheidsintervallen berekend (methode Wilson). Trends in de figuren, bijbehorende percentages en $p$-waarden zijn gebaseerd op de groeicurven $(\log (\mathrm{Y}))$ en geven de jaar op jaar verandering in het percentage rokers in Amsterdam en Nederland. De berekeningen zijn gemaakt met behulp van een GLM binomiale regressie met een log link.

\section{Resultaten}

Figuur 1 geeft voor de periode 1994 tot en met 2016 het percentage inwoners van negentien jaar en ouder dat rookt in Amsterdam en Nederland weer. De figuur laat zien dat het percentage gestaag daalde, onder mannen en onder vrouwen, zowel in Amsterdam als in Nederland. Verder is te zien dat het aandeel rokers in Amsterdam tussen 1994 en 2016 sterker is gedaald dan in heel Nederland (zie tab. 2). De jaarlijkse procentuele afname van het aandeel rokers ten opzichte van het voorgaande jaar was $2,0 \%$ onder mannen in Amsterdam $\left(\mathrm{p}_{\text {trend }}<0,01\right)$, net als landelijk $\left(\mathrm{p}_{\mathrm{nl}-\mathrm{ams}}=0,525\right)$. Onder Amsterdamse vrouwen daalde het aandeel rokers ieder jaar met $2,7 \%$ ( $p_{\text {trend }}<0,01$ ) ten opzichte van het voorgaande jaar. Dat is sterker dan landelijk $(2,4 \%$; $\mathrm{p}_{\text {trend }}<0,01 ; \mathrm{p}_{\text {nl-ams }}<0,01$ ).

Sinds 2008 lijkt de daling in Amsterdam te stagneren, terwijl het aandeel rokers in heel Nederland verder is afgenomen. Als we kijken naar de trend binnen leeftijdsgroepen, herkomstgroepen en oplei-
Figuur 1 Trend in het aandeel rokers tussen 1994 en 2016 in Amsterdam (19 jaar en ouder) en Nederland (18 jaar en ouder) naar geslacht met geschatte trendlijnen (percentages). Bron: Amsterdamse cijfers: Gezondheidsmonitor GGD Amsterdam; landelijke cijfers: Gezondheidsenquête CBS. De gegevens voor Amsterdam zijn gewogen naar de opbouw van de Amsterdamse bevolking in het onderzoeksjaar. De gegevens over Nederland zijn gewogen naar de opbouw van de Nederlandse bevolking in het onderzoeksjaar

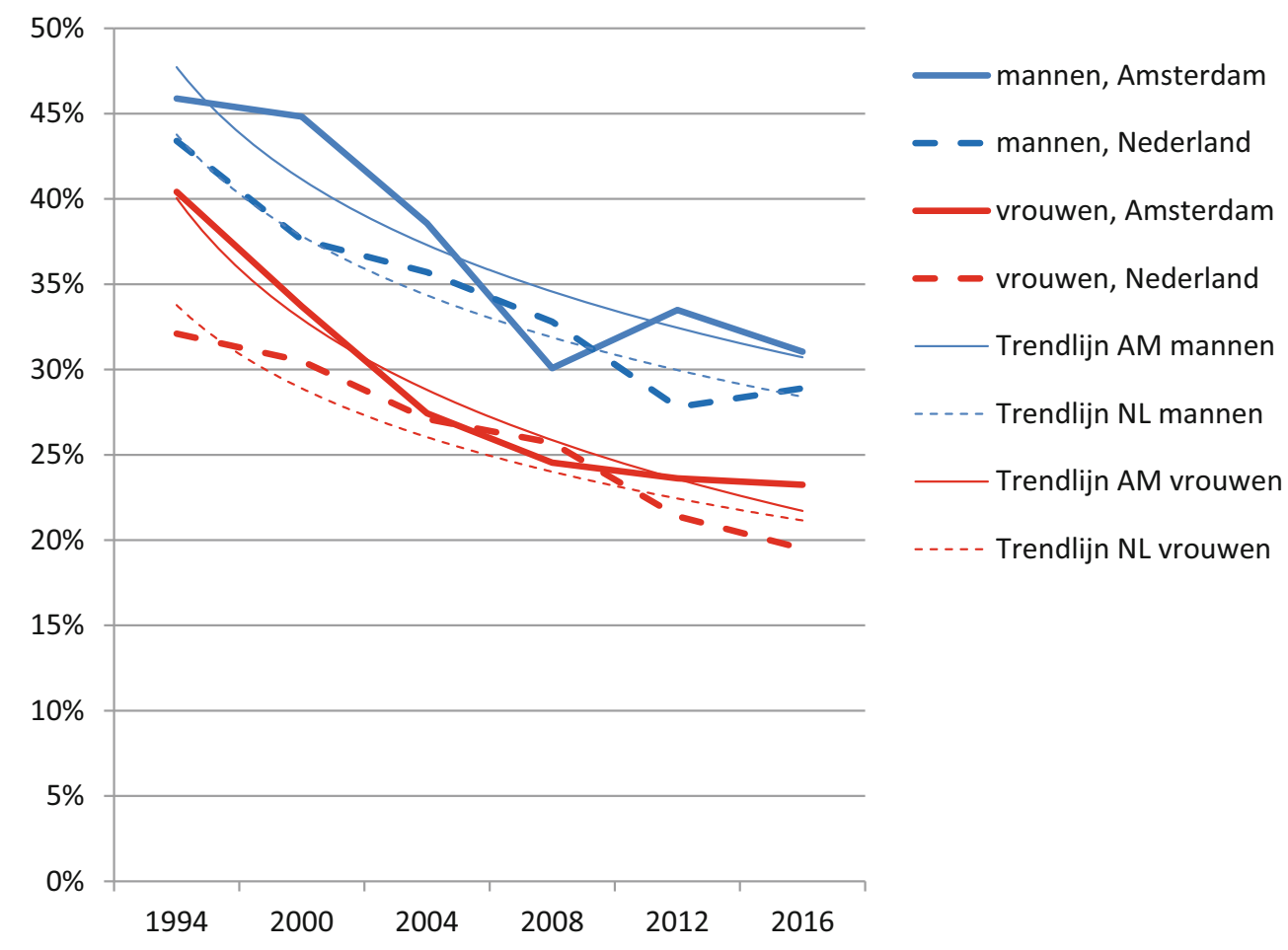


Tabel 2 Trend in het aandeel rokers tussen 1994 en 2016 in Amsterdam (19 jaar en ouder) en Nederland (18 jaar en ouder) naar geslacht (percentages) ${ }^{1}$. Bron: Amsterdamse cijfers: Gezondheidsmonitor GGD Amsterdam; landelijke cijfers: Gezondheidsenquête CBS

\begin{tabular}{|l|l|l|l|}
\hline & & Amsterdam & Nederland \\
\hline Totaal & 1994 & 43,0 & 37,5 \\
\hline & 2000 & 39,1 & 33,9 \\
\hline & 2004 & 33,1 & 31,4 \\
\hline & 2008 & 27,2 & 29,2 \\
\hline & 2012 & 28,4 & 24,5 \\
\hline Mannen & 1994 & 27,1 & 24,1 \\
\hline & 2000 & 44,9 & 43,4 \\
\hline & 2004 & 38,6 & 37,6 \\
\hline & 2008 & 30,1 & 35,7 \\
\hline & 2012 & 33,5 & 32,8 \\
\hline Vrouwen & 2016 & 31,0 & 27,8 \\
\hline & 1994 & 40,4 & 28,9 \\
\hline & 2000 & 33,7 & 32,1 \\
\hline & 2004 & 27,4 & 30,5 \\
\hline & 2008 & 24,5 & 27,1 \\
\hline & 2012 & 23,6 & 25,7 \\
\hline & 2016 & 23,2 & 21,4 \\
\hline
\end{tabular}

dingsniveaus was over het algemeen sprake van een daling van het aandeel rokers van 1994 tot 2004, waarna het cijfer stabiliseerde (zie tab. 3). Uit fig. 1 blijkt verder dat het percentage rokers in Amsterdam in de periode 1994 tot 2016 boven het landelijke cijfer lag, zowel onder mannen $\left(\mathrm{p}_{\mathrm{nl}-\mathrm{ams}}<0,01\right)$ als vrouwen $\left(\mathrm{p}_{\mathrm{nl}-\mathrm{ams}}<0,01\right)$. Alleen in 2008 was het aandeel rokers in Amsterdam bij mannen lager dan gemiddeld in Nederland $(p<0,05)$; bij vrouwen vonden we geen verschil $(p=0,114)$.

Figuur 2 laat de trend in roken onder inwoners van 19 tot en met 74 jaar in Amsterdam zien, waarbij de cijfers zijn gestandaardiseerd naar de leeftijdsverdeling in Nederland in 2000. De trendlijnen komen overeen met die in fig. 1. Dat betekent dat de daling van het percentage rokers in Amsterdam niet in belangrijke mate werd veroorzaakt door een verandering in de leeftijdsopbouw van de bevolking. Verder toont fig. 2 de trend voor dagelijks roken en zwaar roken in de Amsterdamse bevolking van 19 tot en met 74 jaar tussen 1994 en 2016. Onder mannen ging de daling van het percentage dagelijkse rokers $\left(2,2 \% ; \mathrm{p}_{\text {trend }}<0,01\right)$ vrijwel gelijk op met de daling van het aandeel rokers $\left(1,8 \% ; p_{\text {trend }}<0,01\right)$. Onder vrouwen daalde het percentage dagelijkse rokers $(3,9 \%$ ten opzichte van voorgaande jaar; $p_{\text {trend }}<0,01$ ) harder dan het aandeel rokers $\left(2,8 \%\right.$; $\left.p_{\text {trend }}<0,01\right)$. Deze daling
Tabel 3 Trend in het aandeel rokers tussen 1994 en 2016 in Amsterdam (19 jaar en ouder) naar leeftijd, opleidingsniveau en migratieachtergrond (percentages) ${ }^{\mathrm{a}}$. Bron: Gezondheidsmonitor GGD Amsterdam

\begin{tabular}{|c|c|c|c|c|c|c|}
\hline & 1994 & 2000 & 2004 & 2008 & 2012 & 2016 \\
\hline Totaal & 43,0 & 39,1 & 33,1 & 27,2 & 28,4 & 27,1 \\
\hline \multicolumn{7}{|l|}{ Leeftijd } \\
\hline $19-29$ & 48,1 & 46,7 & 37,3 & 28,0 & 35,9 & 33,1 \\
\hline $30-39$ & 46,7 & 39,7 & 31,0 & 27,6 & 32,2 & 27,1 \\
\hline $40-49$ & 48,4 & 42,2 & 36,5 & 28,2 & 27,2 & 25,5 \\
\hline $50-59$ & 37,1 & 38,1 & 36,5 & 33,0 & 27,5 & 28,8 \\
\hline $60-74$ & 34,7 & 30,8 & 26,8 & 24,6 & 20,2 & 22,6 \\
\hline $75+$ & 22,6 & 20,6 & 12,1 & 14,4 & 12,4 & 12,4 \\
\hline \multicolumn{7}{|l|}{ Opleiding $^{b}$} \\
\hline Maximaal basisonderwijs & 40,2 & 38,3 & 32,7 & 27,0 & 27,0 & 24,5 \\
\hline Vmbo & 48,0 & 42,6 & 42,7 & 33,0 & 29,2 & 29,8 \\
\hline Havo, vwo, mbo & 44,2 & 40,1 & 33,6 & 31,3 & 35,2 & 32,4 \\
\hline Hbo, wo & 40,4 & 37,0 & 26,3 & 22,1 & 25,7 & 23,9 \\
\hline \multicolumn{7}{|l|}{ Migratieachtergrond ${ }^{c}$} \\
\hline Nederlands & - & 42,0 & 34,1 & 26,4 & 28,0 & 27,0 \\
\hline Marokkaans & - & 17,4 & 20,0 & 17,0 & 15,6 & 13,2 \\
\hline Turks & - & 47,3 & 42,9 & 38,7 & 42,3 & 40,7 \\
\hline Surinaams & - & 36,4 & 24,5 & 34,1 & 32,8 & 30,3 \\
\hline Overig niet-westers & - & 31,3 & 35,9 & 22,8 & 26,9 & 23,3 \\
\hline Overig westers & - & 41,5 & 34,1 & 30,5 & 28,6 & 30,1 \\
\hline
\end{tabular}

zette na 2008 door. Het percentage zware rokers in de Amsterdamse bevolking nam sinds 1994 zowel onder mannen $\left(\mathrm{p}_{\text {trend }}<0,01\right)$ als onder vrouwen $\left(\mathrm{p}_{\text {trend }}<0,01\right)$ fors af en is ook na 2008 verder gedaald.

In fig. 3 is de ontwikkeling van roken en zwaar roken tussen 1994 en 2016 onder drie leeftijdsgroepen in Amsterdam weergegeven. In alle drie leeftijdsgroepen is het aandeel rokers gedaald met $2,4 \%$ per jaar ten opzichte van het voorgaande jaar $(p<0,01)$. Deze daling wordt gedeeltelijk veroorzaakt door een verandering in de leeftijdsopbouw in de Amsterdamse bevolking $(p<0,01)$. Als we hiermee rekening houden, was de daling 2,2\% per jaar. Er was geen significant verschil in daling tussen de drie leeftijdsgroepen. Het grootste aandeel rokers was zowel in 1994 als in 2016 te vinden onder 19- tot en met 34-jarigen. Het aandeel zware rokers was in 2016 het hoogst onder 40-plussers $(4 \%)$ en het laagst onder 19- tot en met 34-jarigen $(1 \%)$. Vooral onder jongvolwassenen (1994: 17\%; 2016: 1\%) en onder inwoners van middelbare leeftijd (1994: 21\%; 2016: 4\%) is het aandeel zware rokers tussen 1994 en 2016 flink gedaald (jongvolwassenen: $\mathrm{p}_{\text {trend }}<0,01 ; 40$ - tot en met 59-jarigen: $\mathrm{p}_{\text {trend }}<0,01$ ). Onder 60- tot en met 74-jarigen was de afname van het percentage zware rokers van $11 \%$ naar $5 \%$ minder groot $\left(\mathrm{p}_{\text {trend }}<0,01\right)$. De ontwikkeling voor het aandeel 
Figuur 2 Trend in roken, dagelijks roken en zwaar roken onder 19- tot en met 74-jarige Amsterdammers van 1994 tot 2016 naar geslacht, gestandaardiseerd naar de leeftijdsopbouw van Nederland op 1 januari 2000 (percentage). Bron: Gezondheidsmonitor GGD Amsterdam

Figuur 3 Trend in roken en zwaar roken onder 19tot en met 74-jarige Amsterdammers van 1994 tot 2016 naar leeftijd (gewogen percentages). Bron: Gezondheidsmonitor GGD Amsterdam
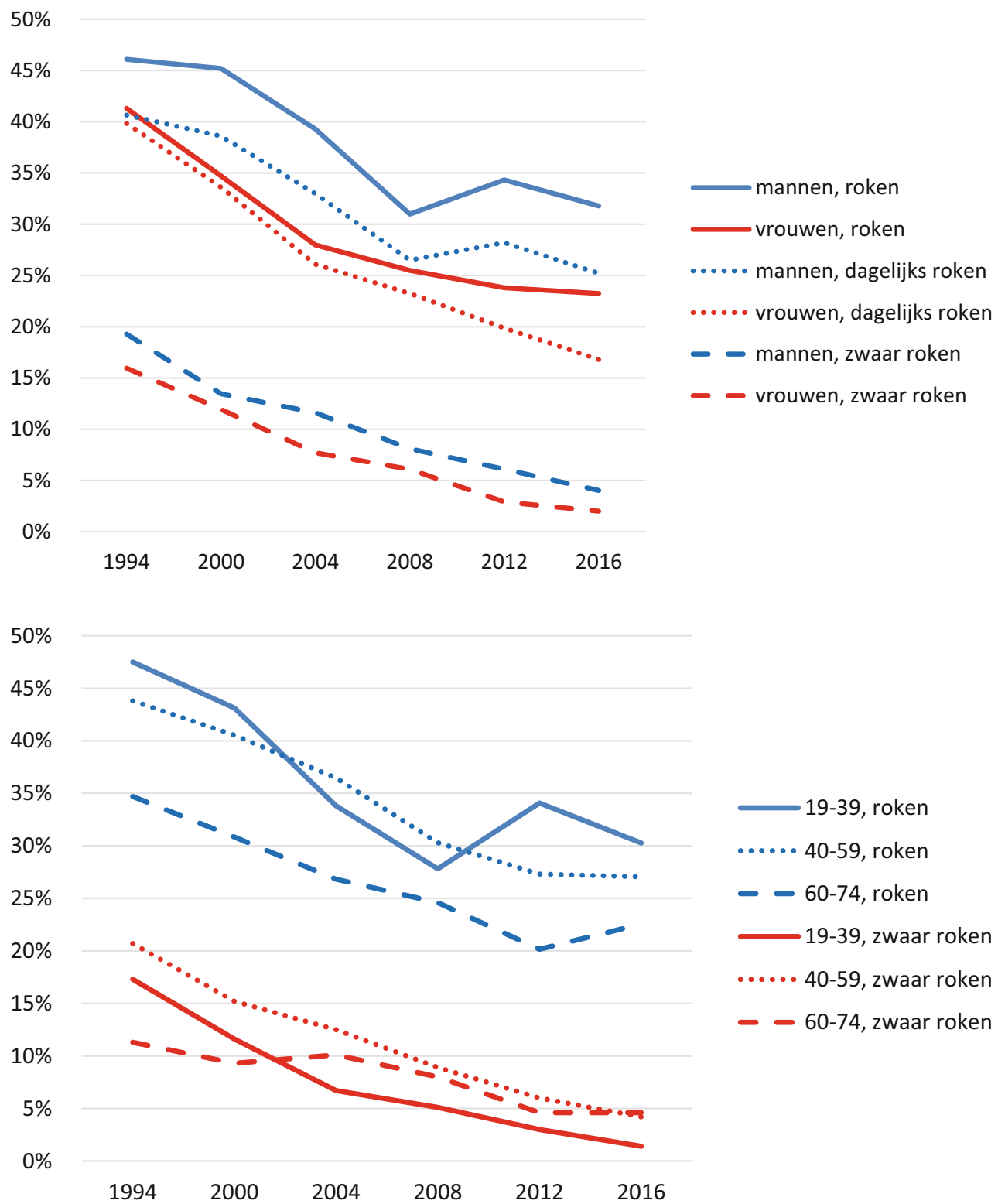

dagelijkse rokers naar leeftijd liep vrijwel parallel aan die van het aandeel rokers (niet in de figuur).

\section{Beschouwing}

In Amsterdam wordt meer gerookt dan gemiddeld in Nederland. Net als elders in Nederland daalde de prevalentie van roken in Amsterdam: van 43\% in 1994 naar $27 \%$ in 2016. Na 2008 is het aandeel rokers onder Amsterdamse mannen en vrouwen gestabiliseerd, terwijl de daling elders in het land doorzette. Wel is in Amsterdam het aandeel dagelijkse en zware rokers in deze periode afgenomen. De afname van het percentage rokers in Amsterdam wordt niet veroorzaakt door een verandering in leeftijdssamenstelling van de bevolking.
Een verklaring voor de hogere prevalentie van roken in Amsterdam is de oververtegenwoordiging van jongvolwassenen in de stad. Het percentage rokers is over het algemeen immers het hoogst onder 25- tot 29-jarigen en neemt daarna af [7]. Ook de voor leeftijd gestandaardiseerde Amsterdamse cijfers liggen echter boven het landelijke cijfer. Dat betekent dat andere factoren eveneens een rol zouden kunnen spelen, zoals het hogere aandeel alleenwonenden in de stad. Ook de sociale omgeving is van belang - jongeren die blijven roken groeien vaak op in een omgeving waarin ook ouders en vrienden roken [9].

Sinds 1990 zijn diverse beleidsmaatregelen geïmplementeerd om roken te ontmoedigen. In welke mate de daling van het aandeel rokers daarmee samenhangt is moeilijk aan te geven. Vooral aan het begin van deze eeuw zijn via de Tabaks- en rookwa- 
renwet verschillende maatregelen ingezet om roken tegen te gaan, zoals een rookverbod in publieke ruimten (2000), het openbaar vervoer (2003) en op de werkplek (2004), en een verbod op tabaksreclame en -sponsoring (2002). Na de invoering van deze maatregelen daalde het aandeel rokers, zowel landelijk als in Amsterdam. In de periode daarna werd op beperktere schaal nieuwe regelgeving doorgevoerd, met als belangrijkste onderdeel het rookverbod in de horeca in 2008, met daarop een uitzondering voor kleine cafés tussen 2011 en 2014 [10]. Na de invoering van het gedeeltelijke rookverbod in de horeca in 2008 was er geen significante afname in rookprevalentie in de algemene bevolking te zien [11]. In 2014 werd de leeftijdsgrens voor de verkoop van tabaksproducten verhoogd naar achttien jaar, wat samenging met een daling van roken onder scholieren [12]. Het geringe aantal preventieve maatregelen tussen 2005 en 2014 kan wellicht het stabiele percentage rokende volwassenen in Amsterdam tussen 2008 en 2016 verklaren. Opvallend is dat het percentage rokers elders in $\mathrm{Ne}$ derland sinds 2008 wel verder daalde. Deze landelijke daling zien we onder zowel mannen als vrouwen, maar onder vrouwen is de daling minder groot dan onder mannen. In Amsterdam lijkt het aandeel rokers juist onder vrouwen sterker te dalen dan onder mannen.

Een effectieve preventieve aanpak van roken bestaat uit een combinatie van maatregelen gericht op verhoging van de prijs van tabaksproducten, een rooken tabaksvrije omgeving, stopondersteuning, intensieve mediacampagnes en product- en verpakkingseisen [5]. Zowel het Amsterdamse tabaksontmoedigingsbeleid uit 2016 en 2019, als het Nationaal Preventieakkoord uit 2018 bestaat uit zo'n gecombineerde aanpak [4, 5, 13]. In Amsterdam wordt al enige tijd ingezet op gedragsverandering door onder andere de Gezonde School-aanpak en de campagne Stoptober. In het huidige tabaksontmoedigingsbeleid is steeds meer aandacht voor een rook- en tabaksvrije omgeving. Zo zijn diverse kind- en zorgomgevingen in Amsterdam rookvrij geworden en worden rookvrije zones in de openbare ruimte ingericht [13]. Samen met de maatregelen die de nationale overheid de komende jaren neemt (onder andere het verhogen van de accijns en afbouwen van het aantal verkooppunten) is rookvrij de norm en kan dit beleid resulteren in een sterke daling van het aandeel rokers in Amsterdam.

In dit onderzoek hebben we trendcijfers berekend voor roken in Amsterdam op basis van gegevens uit de periodieke, grootschalige Gezondheidsmonitor van de GGD Amsterdam. De opzet van de Gezondheidsmonitor was in de verschillende onderzoeksjaren vergelijkbaar. Er werd een steekproef uit het bevolkingsregister getrokken van zelfstandig wonende inwoners van Amsterdam aan wie werd gevraagd om mee te werken aan het onderzoek. Op enkele punten varieerde het onderzoek in de verschillende onderzoeksjaren. Zo werden tot 2004 mondelinge interviews gebruikt bij de dataverzameling, terwijl vanaf 2008 voornamelijk schriftelijke en digitale vragenlijsten werden ingezet. Ook liep de omvang van de onderzoekspopulatie uiteen van 1.736 in 2004 tot 8.869 in 2016 en was de enquêtevraag over rookgedrag niet in alle jaren exact hetzelfde. De respons op het onderzoek daalde van $61 \%$ in 1994 naar $38 \%$ in 2016 . Ook de opzet van de steekproef varieerde door de jaren heen. In sommige meetjaren werd de steekproef gestratificeerd naar wijk of stadsdeel, in andere jaren zijn bepaalde herkomstgroepen oversampled. Door de onderzoeksgegevens te wegen naar de bevolkingsopbouw van Amsterdam is voor de steekproefstratificatie en gedeeltelijk ook voor de non-respons gecorrigeerd. We verwachten dat deze verschillen in onderzoeksopzet en uitvoering niet of nauwelijks effect hebben gehad op de uitkomsten, omdat de trends vergelijkbaar zijn met de landelijke cijfers uit de CBS-gezondheidsenquête en ook de risicogroepen overeenkomen met het landelijke beeld.

Een beperking van ons onderzoek is verder dat we als indicator voor dagelijks roken gebruik moesten maken van het gemiddelde aantal gerookte sigaretten per dag, omdat dagelijks roken in de Gezondheidsmonitor niet rechtstreeks is uitgevraagd. Rokers die aangaven dat zij gemiddeld minimaal 1 sigaret per dag roken werden beschouwd als dagelijkse rokers. In de landelijke CBS-gezondheidsenquête wordt direct aan respondenten gevraagd of ze dagelijks roken. In 2016 bleek dat driekwart van de rokers in Nederland tot de dagelijkse rokers behoorde [7]. Ook in de Gezondheidsmonitor kunnen we op basis van onze indicator driekwart van de rokers tot de dagelijkse rokers rekenen: in 2016 rookte $27,9 \%$ van de 19 - tot en met 74 -jarige Amsterdammers en rookte $21,1 \%$ van de 19 tot en met 74 -jarige Amsterdammers gemiddeld minimaal 1 sigaret per dag.

Het percentage rokers is in Amsterdam tussen 1994 en 2016 gedaald, net als in de rest van Nederland, maar helaas is deze afname in Amsterdam de laatste tien jaar gestagneerd. Verheugend is de gestage daling van het aandeel zware rokers in Amsterdam. Zorgwekkend is dat vooral onder jongvolwassen inwoners van Amsterdam het aandeel rokers nog steeds aanzienlijk is - ongeveer een derde van hen rookt weleens. Ook landelijk is dat het geval [14]. Het doel van een rookvrije generatie lijkt daarmee nog ver weg. Opvallend is dat Amsterdamse rokers steeds vaker gelegenheidsrokers zijn. Ze roken niet iedere dag, maar bijvoorbeeld bij het uitgaan, op feestjes of andere gelegenheden. Feit is dat er nog steeds nieuwe rokers bij komen, terwijl het aantal scholieren dat rookt door de strengere wetgeving daalt [12]. Extra beleidsinspanningen zijn nodig om het streefpercentage van 5\% rokers in 2040 in Amsterdam te kunnen bereiken. Daarbij mogen vooral de jongvolwassenen, een aanzienlijke groep in Amsterdam, niet vergeten worden. 
Dankbetuiging We willen Rianca Scheffel van de GGD Amsterdam bedanken voor haar adviezen bij het schrijven van dit artikel.

Open Access This article is licensed under a Creative Commons Attribution 4.0 International License, which permits use, sharing, adaptation, distribution and reproduction in any medium or format, as long as you give appropriate credit to the original author(s) and the source, provide a link to the Creative Commons licence, and indicate if changes were made. The images or other third party material in this article are included in the article's Creative Commons licence, unless indicated otherwise in a credit line to the material. If material is not included in the article's Creative Commons licence and your intended use is not permitted by statutory regulation or exceeds the permitted use, you will need to obtain permission directly from the copyright holder. To view a copy of this licence, visit http://creativecommons.org/licenses/by/4.0/.

\section{Literatuur}

1. Poos MJJC, Bieleman EL, Gommer AM. Sterfte door roken. Bilthoven: RIVM. 2019. https://www. volksgezondheidenzorg.info/onderwerp/roken/cijferscontext/gevolgen\#node-sterfte-door-roken. Geraadpleegd op: 11 jul 2019.

2. Koninkrijk der Nederlanden. Tabaks- en rookwarenwet. Staatsblad 1988, 342. Den Haag: Ministerie van Justitie, 1988. https://wetten.overheid.nl/BWBR0004302/ 2018-11-17. Geraadpleegd op 11 juli 2019.

3. Zorginstituut Nederland. Stoppen-met-roken programma. Diemen: Zorginstituut Nederland.. https://www. zorginstituutnederland.nl/Verzekerde+zorg/s/stoppenmet-roken-zvw. Geraadpleegd op: 11 jul 2019.
4. Ministerie van Volksgezondheid, Welzijn en Sport. Nationaal preventieakkoord Naar een gezonder Nederland. Den Haag: Ministerie van Volksgezondheid, Welzijn en Sport; 2018.

5. GGD Amsterdam. Tabaksontmoedigingsbeleid 2016-2019. Amsterdam: GGD Amsterdam;2016.

6. Bruggink JW. Ontwikkelingen in het aandeel rokers in Nederland sinds 1989. Tijdschr Gezondheidswet. 2013;91:234-40.

7. Zantinge EM, Plasmans MHD, Wilk EA van der. Trend in roken volwassenen 1990-2018. Bilthoven: RIVM. 2020. https://www.volksgezondheidenzorg.info/onderwerp/ roken/cijfers-context/trends\#node-trend-roken-volwa ssenen. Geraadpleegd op: 12 okt 2020.

8. Jager FF. Volksgezondheidenzorg.info. Zorggegevens. Gezondheidsenquête. Bilthoven: RIVM. 2020. https:// bronnen.zorggegevens.nl/Bron?naam=Gezondheidsenq uete. Geraadpleegd op: 23 nov 2020.

9. Kleinjan M, Willemsen M, Bommelé J. Rookpreventie bij jongeren. Effectieve interventies en andere mogelijkheden voor preventie van roken bij jongeren. Utrecht: Trimbosinstituut; 2019.

10. Willemsen MC. Het Nederlandse tabaksontmoedigingsbeleid; mijlpalen in het verleden en een blik op de toekomst. Ned Tijdschr Geneesk. 2017;161:D949.

11. Buisman R, Blankers M, Laar M van. Factsheet rookvrije horeca. Utrecht: Trimbos-instituut; 2015.

12. Monshouwer K, Gommer AM. Trend rookgedrag scholieren 1999-2019. Bilthoven: RIVM. 2020. https://www. volksgezondheidenzorg.info/onderwerp/roken/cijferscontext/trends\#node-trend-roken-scholieren. Geraadpleegd op: 12 okt 2020.

13. GGD Amsterdam. Samen naar een rookvrij Amsterdam. Amsterdam: GGD Amsterdam; 2019.

14. Bommelé J, Willemsen M. Kerncijfers roken 2019. Utrecht: Trimbos-instituut; 2020 . 